\title{
5-Aminolevulinic Acid-Induced Fluorescence in Cerebellar Primary Central Nervous System Lymphoma: A Case Report and Literature Review
}

\author{
Serebellar Yerleşimli Primer Santral Sinir Sistemi Lenfomasinda \\ 5-Aminolevülinik Asit ile İndüklenmiş Floresans: Olgu Sunumu ve \\ Literatür Derlemesi
}

Junkoh YAMAMOTO, Takehiro KITAGAWA, Daisuke AKIBA, Shigeru NISHIZAWA

University of Occupational and Environmental Health, Department of Neurosurgery, Kitakyushu, Japan

Corresponding Author: Junkoh YAMAMOTO / E-mail: yama9218@med.uoeh-u.ac.jp

\begin{abstract}
5-Aminolevulinic acid (5-ALA)-induced fluorescence-guided resection is a widely used procedure for patients with malignant gliomas. However, the clinical application of 5-ALA for surgery in primary central nervous system lymphoma (PCNSL) is uncommon. Here, we present a case of PCNSL treated using 5-ALA-induced fluorescence-guided resective surgery. A 70-year-old woman presented with cerebellar ataxia, and magnetic resonance imaging revealed an irregularly shaped and homogenously enhanced mass with surrounding brain edema in the vermis that extended to the right hemisphere of the cerebellum. Under the preoperative diagnosis of a malignant glioma in the cerebellum, the patient underwent 5-ALA-induced fluorescence-guided surgery. Under blue light illumination, the tumor revealed strong 5-ALA-induced fluorescence. The tumor was identified as a diffuse large B-cell lymphoma. After partial resection, the patient received adjuvant chemotherapy and radiotherapy. Importantly, the neurological deficit of the patient improved, and recurrence of the tumor was not observed 21 months post-surgery. Together with previous reports, this case study emphasizes the efficacy of the surgical application of 5-ALA for PCNSL.
\end{abstract}

KEYWORDS: Glioma, Subventricular zone, Ependyma, Surgery, Diffuse large B-cell lymphoma, Dissemination, 5-ALA

öz

5-Aminolevülinik asit (5-ALA) ile indüklenmiş floresans-eşliğinde rezeksiyon malign gliomalı hastalarda yaygın kullanılan bir tekniktir. Ancak primer santral sinir sistemi lenfoması (PSSSL) olan hastaların cerrahisinde 5-ALA kullanımı sık değildir. Burada 5-ALA ile indüklenmiş floresans eşliğinde rezektif cerrahi uygulanan bir PSSSL olgusu sunuldu. Serebellar ataksi ile başvuran 70 yaşındaki kadın hastada manyetik rezonans görüntüleme, vermisden sağ serebellar hemisfere uzanan, düzensiz sınırlı ve homojen kontrast tutan, çevre beyin dokusunda ödeme nedene olan kitle lezyonunu ortaya koydu. Preoperatif olarak serebellumda malign glioma tanısı düşünüldü ve hastaya 5-ALA ile indüklenmiş floresans eşliğinde cerrahi uygulandı. Mavi ışık aydınlatması altında tümör kuvvetli 5-ALA ile indüklenmiş floresans gösterdi. Tümörün histopatolojik inceleme sonucu diffüz geniş B-hücreli lenfoma olarak geldi. Kısmi rezeksiyondan sonra hastaya ilave kemoterapi ve radyoterapi uygulandı. Önemli olarak, hastanın nörolojik defisiti düzeldi ve cerrahiden 21 ay sonra nüks gözlenmedi. Bu konudaki daha önceki raporlarla birlikte, bu olgu çalışması da 5-ALA'nın PSSSL'da cerrahi uygulamasının etkinliğini vurgulamaktadır.

ANAHTAR SÖZCÜKLER: Glioma, Subventriküler bölge, Epandim, Cerrahi, Diffüz geniş B-hücreli lenfoma, Yayılım, 5-ALA

\section{INTRODUCTION}

5-Aminolevulinic acid (5-ALA) is a natural biochemical precursor of heme that induces the synthesis and accumulation of fluorescent porphyrins such as protoporphyrin IX (PpIX) in various cancerous tissues (17). Because 5-ALA can lead to PpIX accumulation within malignant glioma tissues, 5-ALA is primarily applied for fluorescence-guided resection of malignant gliomas by using specifically modified neurosurgical microscopes (10). Recently, 5-ALA has also been identified as a promising intraoperative marker in stereotaxic biopsies for malignant gliomas $(5,15)$. However, clinical application of 5 -ALA in primary central nervous system lymphoma (PCNSL) is currently uncommon $(2,8,12)$.
Here, we report a case of cerebellar PCNSL demonstrating strong 5-ALA-induced fluorescence via open resective surgery. Furthermore, we discuss the usefulness of 5-ALA in surgery for PCNSL, and review relevant literature.

\section{CASE REPORT}

A 70-year-old woman with diabetes mellitus experienced progressive gait disturbance and consulted our hospital. Neurological examination revealed right-sided dysmetria and an unstable wide gait. Blood sugar level on arrival and $\mathrm{HbA} 1 \mathrm{c}$ were $169 \mathrm{mg} / \mathrm{dL}$ and $6.2 \%$, respectively. Tests to determine serum soluble interleukin-2 receptor levels indicated no abnormalities $(292.0 \mathrm{U} / \mathrm{mL})$. Serological examination for infections and collagen disease was unremarkable. Brain 
computed tomography (CT) showed ill-defined mixed density (iso- and hypo) lesion in the cerebellum (Figure 1A). Magnetic resonance imaging (MRI) revealed an irregularly shaped and relatively homogenously enhanced mass with surrounding brain edema (Figures 1B-F). This intra-axial mass was located mainly in the cerebellar vermis and extended to the right hemisphere of the cerebellum. A diffusion-weighted image showed mild fluid restriction (Figures 1D), and a map of regional cerebellar blood volume from a perfusion-weighted image indicated increased blood flow (Figure 1G). Under the preoperative diagnosis of a malignant glioma in the cerebellum, and according to a previously described protocol (10), the patient underwent 5-ALA-induced fluorescence- guided surgery. Via a midline suboccipital craniotomy, a small corticotomy was performed at the boundary zone between the cerebellar vermis and right cerebellar hemisphere. The tumor was identified in deep cerebellar white matter (Figures $2 \mathrm{~A}, \mathrm{~B})$. Blue light illumination of the tumor revealed the typical strong red fluorescence under a 410-nm ultraviolet light source (OPMI/Pentero, Carl Zeiss, Oberkochen, Germany) (Figure $2 \mathrm{C}$ ). Because the pathological examination during the surgery confirmed the suspected malignant lymphoma, the fluorescent tumor tissue was partially resected. Histological examination of tumor specimen showed a high cellular malignancy composed of large cells with elongated, irregular nuclei (Figure $3 \mathrm{~A}$ ). The tumor cells were immunoreactive for
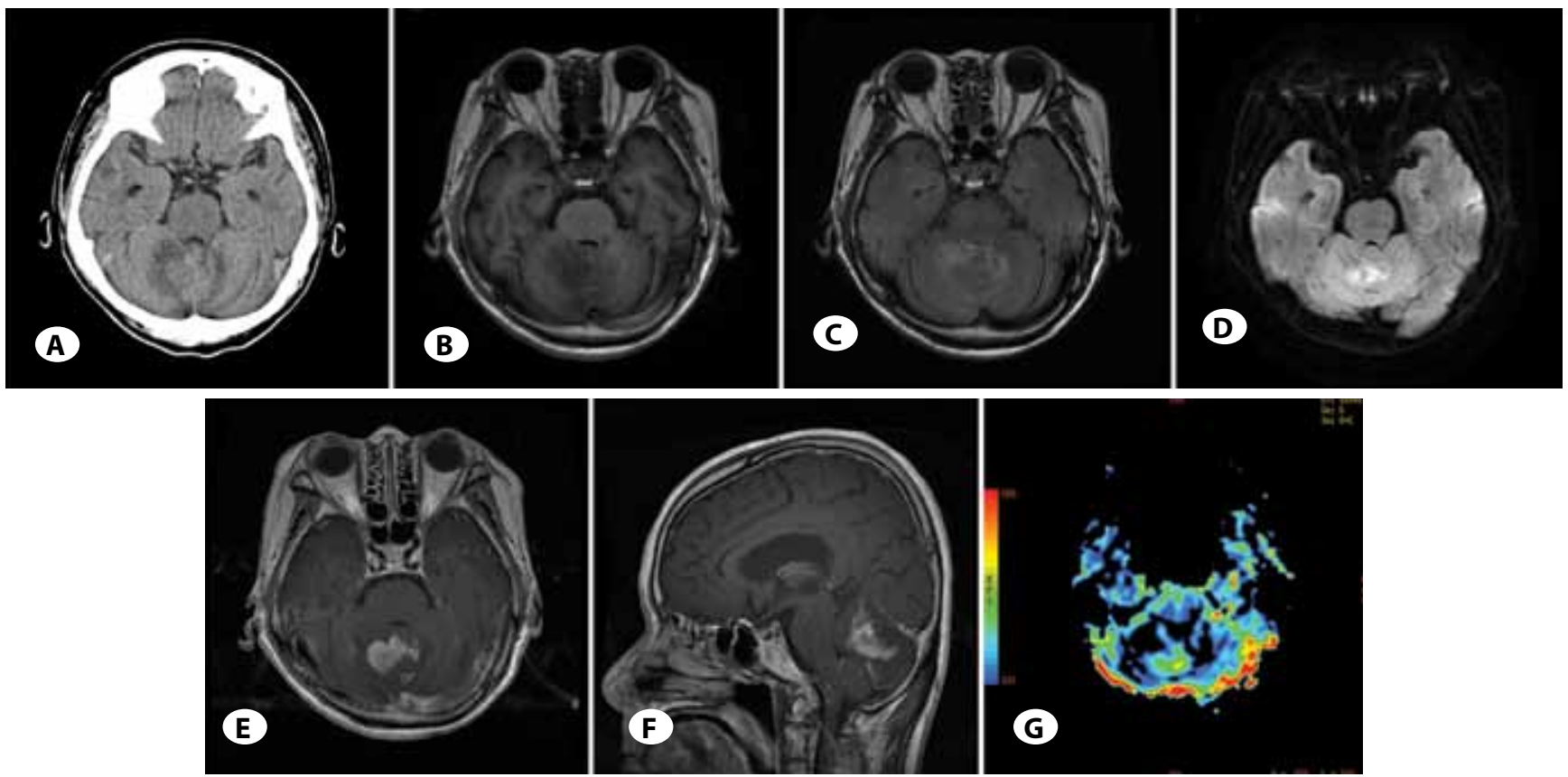

Figure 1: Computed tomography (CT) and magnetic resonance imaging (MRI) performed on admission. Axial CT image (A), T1weighted image (T1WI) (B), fluid-attenuated inversion recovery (FLAIR) image (C), diffusion-weighted image (DWI) (D), axial (E) and sagittal (F) contrast-enhanced T1WIs (E), and axial image of a regional cerebellar blood volume map on perfusion-weighted image (PWI) (G). MRI demonstrating an irregularly shaped and relatively homogenously enhanced mass on the vermis extending to the right hemisphere of the cerebellum with surrounding brain edema (B-D). PWI showing high blood flow within the tumor (G).
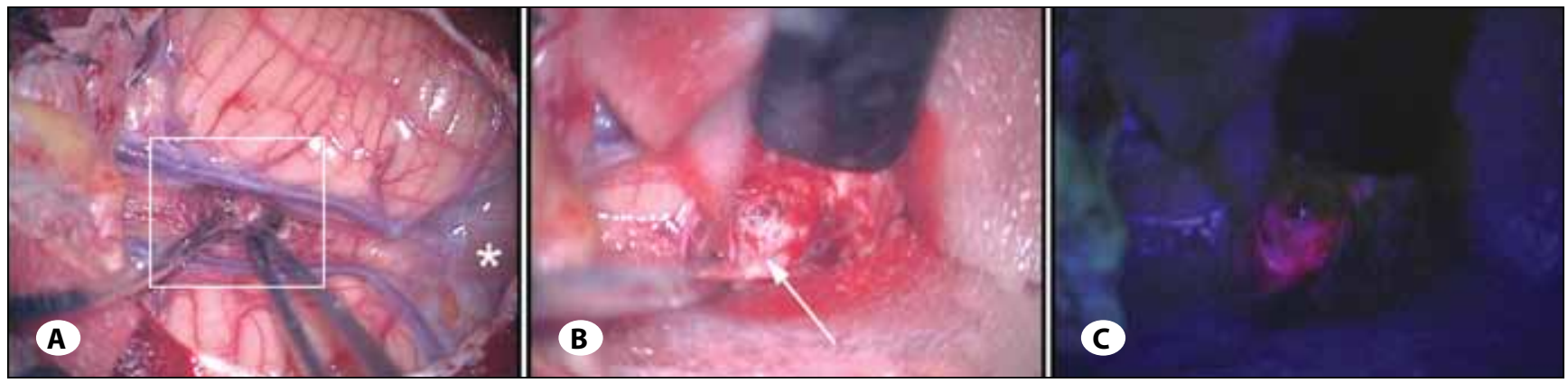

Figure 2: Intraoperative photograph of the tumor resection (A-C). B and C correspond to the square in A. After the suboccipital craniectomy, a small corticotomy was performed at the boundary zone between the vermis and right cerebellar hemisphere (A). The tumor was identified in deep cerebellar white matter (arrow in B). The tumor was strongly fluorescent under the violet-blue excitation light (C). The asterisk in $A$ is the cerebellomedullary cistern. 
a B cell marker (CD20) (Figure 3B), but not for a T cell marker (CD3) (Figure $3 C$ ). The proliferation index (Ki-67) was $92 \%$ (Figure 3D). These findings were compatible with diffuse large B-cell lymphoma (DLBCL). Whole-spine MRI and body CT showed no abnormalities. Ophthalmological examination excluded intraocular lesions. Thus, we diagnosed the patient with PCNSL.

According to a previously described protocol (6), the patient underwent the first course of high-dose methotrexate therapy

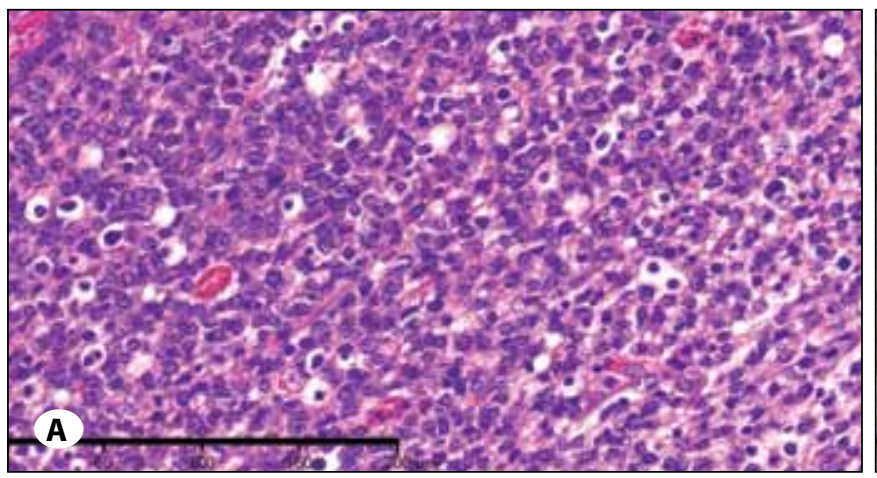

(HD-MTX). Because of mild renal dysfunction, the patient could not receive the next course of HD-MTX. Thus, the patient underwent subsequent radiotherapy. The patient's condition improved without any other neurological deficit. No recurrence of the tumor was detected on MRI performed 21 months after the surgery (Figure 4A, B).

\section{DISCUSSION}

The number of clinical cases using 5-ALA for PCNSL is extremely low compared to the number of cases using 5-ALA
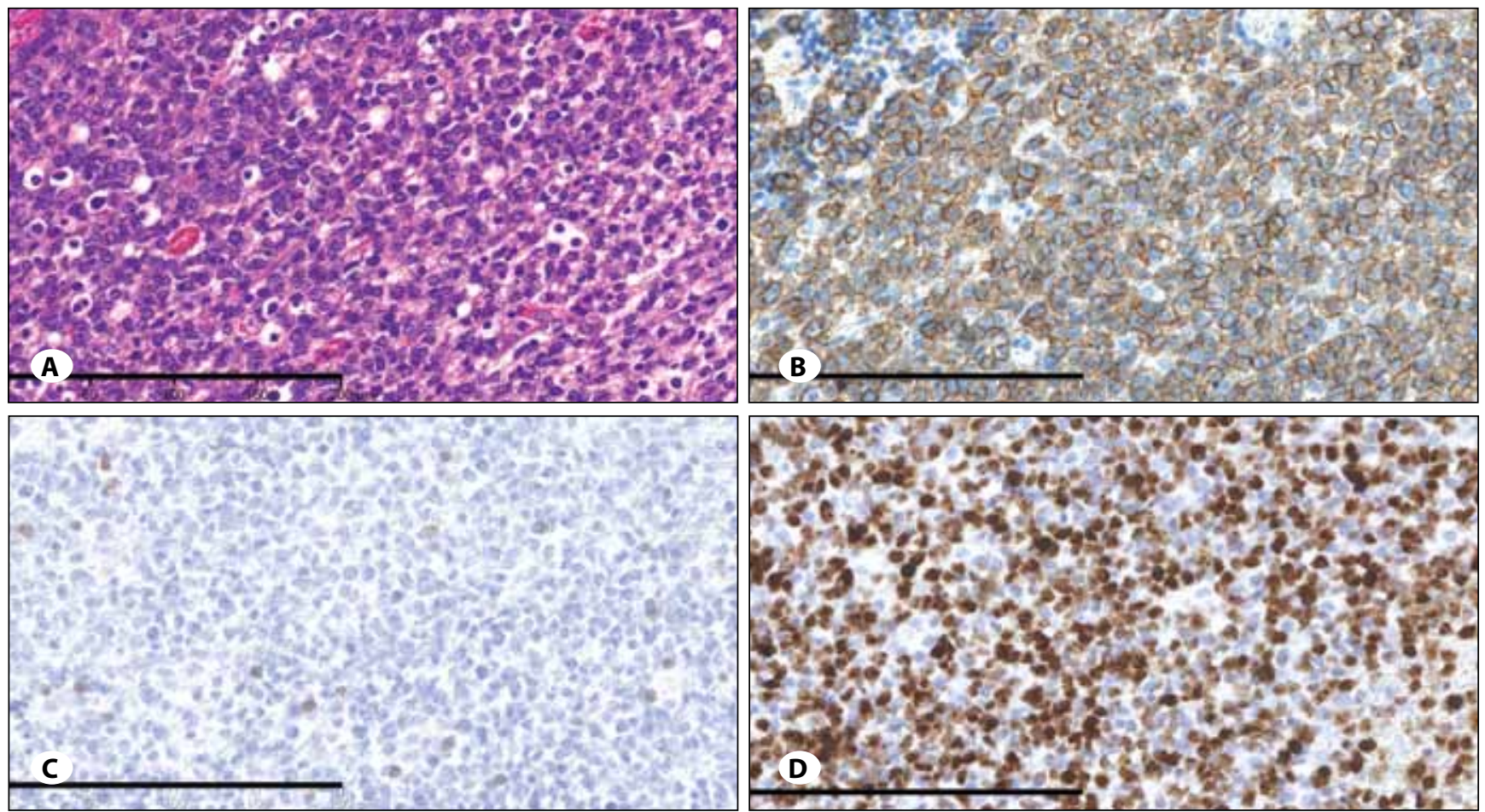

Figure 3: Diffuse large B-cell lymphoma. Hematoxylin and eosin staining from the specimen that demonstrated strong 5-ALAinduced fluorescence lesion showed a high cellular malignancy composed of large cells with elongated, irregular nuclei (A). Immunohistochemical examination showed that the tumor strongly expressed CD20 (B). The tumor lacked CD3 expression, with retained expression in intermingled and small reactive T lymphocytes (C). MIB-1 (Ki-67) shows a high proliferative index (D). Scale bar $200 \mu \mathrm{m}$ (A-D).
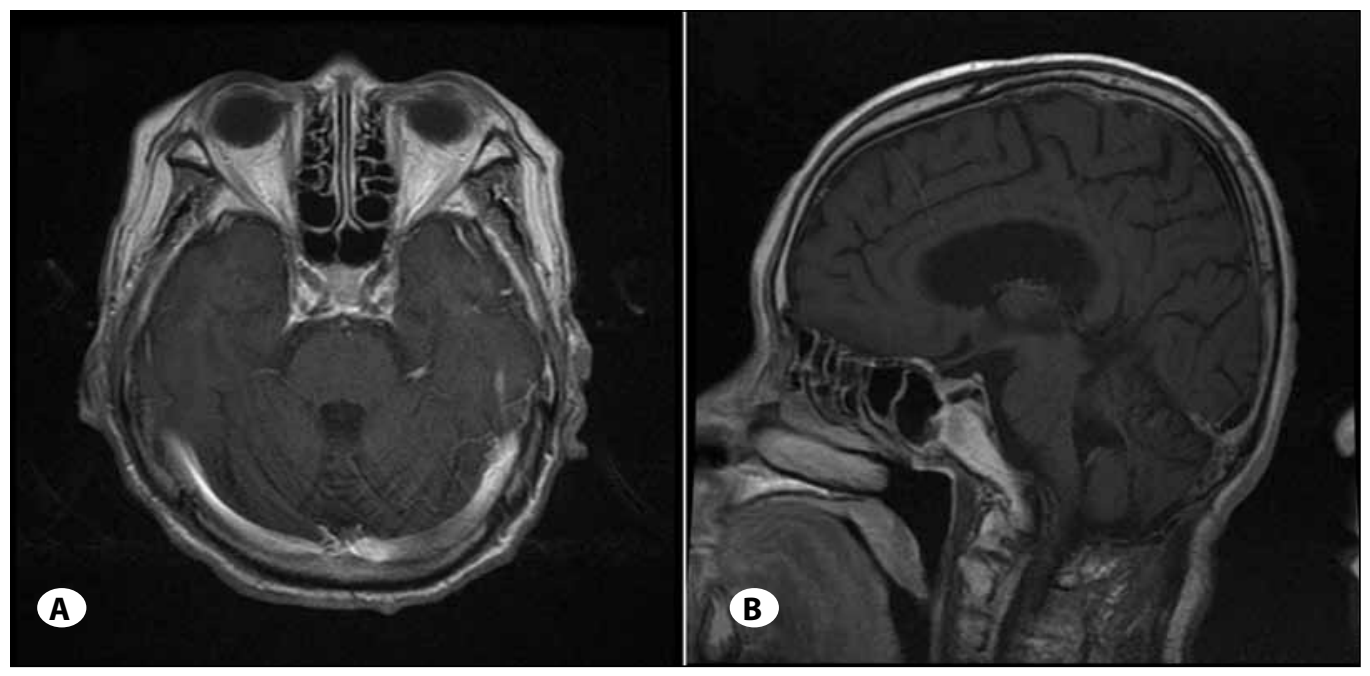

Figure 4: Follow-up MRI performed 21 months after the surgery. Axial (A) and sagittal (B) contrastenhanced T1Wls. No tumor recurrence was detected. $R$ in $A$, and $A$ in $B$ mean right side and anterior side, respectively. 
Table I: Summary of Studies on CNS Lymphoma Demonstrating 5-ALA-Induced Fluorescence

\begin{tabular}{|c|c|c|c|c|c|c|}
\hline \multicolumn{7}{|c|}{ Summary of CNS lymphoma demonstrating 5-ALA-induced fluorescence } \\
\hline \multirow[b]{2}{*}{ Authors (year) } & \multirow[b]{2}{*}{$\begin{array}{l}\text { Patients } \\
\text { (n) }\end{array}$} & \multirow[b]{2}{*}{ Pathology } & \multirow[b]{2}{*}{ Surgery } & \multicolumn{3}{|c|}{ 5-ALA fluorescence status } \\
\hline & & & & $\begin{array}{c}\text { Strong } \\
\%\end{array}$ & $\begin{array}{l}\text { Vague } \\
\%\end{array}$ & $\begin{array}{c}\text { None } \\
\%\end{array}$ \\
\hline Moriuchi et al. (2011) (8) & 1 & DLBCL & stereotaxic biopsy & 100 & - & - \\
\hline Utsuki et al. (2011) (12) & 20 & $\begin{array}{l}\text { malignant } \\
\text { lymphoma }\end{array}$ & $\begin{array}{l}\text { stereotaxic biopsy (one case), } \\
\text { others; no information }\end{array}$ & 60 & 20 & 20 \\
\hline Widhalm et al. (2012) (14) & 7 & CNS lymphoma & stereotaxic biopsy & 88 & 12 & - \\
\hline von Campe et al. (2012) & 4 & DLBCL & stereotaxic biopsy & 100 & - & - \\
\hline Grossman et al. (2014) (2) & 1 & DLBCL & suboccipital craniectomy & 100 & - & - \\
\hline Present case & 1 & DLBCL & suboccipital craniectomy & 100 & - & - \\
\hline
\end{tabular}

Abbreviation: DLBCL, diffuse large B-cell lymphoma.

for malignant gliomas. Only 33 cases of 5-ALA-induced fluorescence-guided surgery have been reported (Table I). Except for one reported case, patients with PCNSL commonly undergo stereotaxic biopsy. Only one case of 5-ALA-induced fluorescence-guided surgery via the open resective approach for PCNSL that was located on the floor of the fourth ventricle has been reported (2). Almost all cases were positive (strong and vague) for 5-ALA-induced fluorescence. However, one study reported that $20 \%$ of PCNSL cases lacked 5-ALA-induced fluorescence (12). In the present case, we chose an open resective approach to the cerebellar tumor, without exposing the fourth ventricle, and observed strong 5-ALA-induced fluorescence of the tumor that was histologically compatible with DLBCL. The tumor also had a high proliferation index. Previously, 5-ALA-induced fluorescence intensity in malignant gliomas was correlated with three factors: 1) high cellular density, 2) high proliferation index, and 3) high neovascularity (11). Although the precise pathogenesis of 5-ALA-induced fluorescence in PCNSL is unclear, PCNSL with high cellular density and proliferation index correlates strongly with intense 5-ALA-induced fluorescence. Therefore, in agreement with a previous report (14), we propose that 5-ALA-induced fluorescence in PCNSL plays an important role in tumor detection via open surgery as an intraoperative marker to confirm the precise biopsy target in stereotaxic biopsy.

A recent study showed improved survival following resection, but not biopsy, of PCNSL (13). Interestingly, 5-ALA-induced fluorescence-guided resection may apply to PCNSL in a similar way surgery applies to malignant gliomas (2). Typically, PCNSLs are supratentorial (75-85\%) and appear as a mass or multiple masses that commonly contact the subarachnoid or ependymal surface (7). Recently, in patients with malignant gliomas and PCNSL, 5-ALA-induced fluorescence of the ventricular wall adjacent to the tumor was discovered and considered as tumor infiltration or dissemination (13). We previously reported glioblastoma presenting with mesial temporal epilepsy in the right temporal lobe (16); the patient underwent tumor resection and right selective hippocampectomy to treat the mesial temporal epilepsy. During the surgery, the surface of the hippocampus revealed strong 5-ALA-induced fluorescence. However, pathological investigation of the hippocampus showed neither tumor invasion nor disruption of the ependymal layer. Moreover, previous work using a rat brain tumor model found 5-ALAinduced fluorescence not only in the choroid plexus, but also in the ventricular wall of the contralateral side of the lesion (4). A likely scenario involves tumor-secreted porphyrin leaking into the blood through a defective blood-brain barrier, then spreading through the cerebrospinal fluid to the choroid plexus $(4,9)$, and, consequently, undergoing direct uptake into the ventricular wall. Therefore, if the tumor infiltrates into the subependymal layer, then 5-ALA-induced fluorescence should be observed in the ventricular wall. However, if there is no histological confirmation, 5-ALA-induced fluorescence in the ventricular wall does not necessarily demonstrate the presence of tumor cells. Therefore, we caution that neurosurgeons should carefully interpret 5-ALA-induced fluorescence in the ventricular wall during surgery for PCNSL.

\section{CONCLUSION}

The present case demonstrates that 5-ALA-induced fluorescence serves as a useful diagnostic adjunct for PCNSL under the open resective approach. Together with previous studies, we propose that 5-ALA provides highly specific intraoperative tumor identification in PCNSL. Furthermore, these data suggest that the application of 5-ALA may be extended to open surgery and stereotaxic biopsy in PCNSL.

\section{REFERENCES}

1. Cage TA, Pekmezci M, Prados M, Berger MS: Subependymal spread of recurrent glioblastoma detected with the intraoperative use of 5-aminolevulinic acid: Case report. J Neurosurg 118:1220-1223, 2013

2. Grossman R, Nossek E, Shimony N, Raz M, Ram Z: Intraoperative 5-aminolevulinic acid-induced fluorescence in primary central nervous system lymphoma. J Neurosurg 120:67-69, 2014 
3. Hayashi Y, Nakada M, Tanaka S, Uchiyama N, Kita D, Hamada J: Implication of 5-aminolevulinic acid fluorescence of the ventricular wall for postoperative communicating hydrocephalus associated with cerebrospinal fluid dissemination in patients with glioblastoma multiforme: A report of 7 cases. J Neurosurg 112:1015-1019, 2010

4. Hebeda KM, Saarnak AE, Olivo M, Sterenborg HJ, Wolbers JG: 5-Aminolevulinic acid induced endogenous porphyrin fluorescence in $9 \mathrm{~L}$ and $\mathrm{C} 6$ brain tumours and in the normal rat brain. Acta Neurochir (Wien) 140:503-512; discussion 1213, 1998

5. Hefti M, von Campe G, Moschopulos M, Siegner A, Looser $\mathrm{H}$, Landolt $\mathrm{H}$ : 5 -aminolevulinic acid induced protoporphyrin IX fluorescence in high-grade glioma surgery: A one-year experience at a single institutuion. Swiss Med Wkly 138: 180-185, 2008

6. Hiraga S, Arita N, Ohnishi T, Kohmura E, Yamamoto K, Oku $Y$, et al: Rapid infusion of high-dose methotrexate resulting in enhanced penetration into cerebrospinal fluid and intensified tumor response in primary central nervous system lymphomas. J Neurosurg 91:221-230, 1999

7. Jack CR Jr, Reese DF, Scheithauer BW: Radiographic findings in 32 cases of primary CNS lymphoma. AJR Am J Roentgenol 146:271-276, 1986

8. Moriuchi S, Yamada K, Dehara M, Teramoto Y, Soda T, Imakita $M$, et al: Use of 5-aminolevulinic acid for the confirmation of deep-seated brain tumors during stereotactic biopsy. Report of 2 cases. J Neurosurg 115:278-280, 2011

9. Novotny A, Xiang J, Stummer W, Teuscher NS, Smith DE, Keep RF: Mechanisms of 5-aminolevulinic acid uptake at the choroid plexus. J Neurochem 75:321-328, 2000
10. Stummer W, Pichlmeier U, Meinel T, Wiestler OD, Zanella F, Reulen HJ: Fluorescence-guided surgery with 5-aminolevulinic acid for resection of malignant glioma: $\mathrm{A}$ randomised controlled multicentre phase III trial. Lancet Oncol 7:392-401, 2006

11. Stummer W, Reulen HJ, Novotny A, Stepp H, Tonn JC: Fluorescence-guided resections of malignant gliomas-an overview. Acta Neurochir Suppl 88:9-12, 2003

12. Utsuki S, Oka H, Fujii K: Intraoperative photodynamic diagnosis of brain tumors using 5-aminolevlunic acid. In: Abujamra AL (ed), Diagnostic Techniques and Surgical Management of Brain Tumors. In Tech, 2011: 227-244

13. Weller M, Martus $P$, Roth $P$, Thiel E, Korfel A: Surgery for primary CNS lymphoma? Challenging a paradigm. Neuro Oncol 14:1481-1484, 2012

14. Widhalm G, Minchev G, Woehrer A, Preusser M, Kiesel B, Furtner J, et al: Strong 5-aminolevulinic acid-induced fluorescence is a novel intraoperative marker for representative tissue samples in stereotactic brain tumor biopsies. Neurosurg Rev 35:381-391; discussion 91, 2012

15. Widhalm G, Wolfsberger S, Minchev G, Woehrer A, Krssak M, Czech $\mathrm{T}$, et al: 5-Aminolevulinic acid is a promising marker for detection of anaplastic foci in diffusely infiltrating gliomas with nonsignificant contrast enhancement. Cancer 116: 1545-1552, 2010

16. Yamamoto J, Takahashi M, Idei M, Nakano Y, Soejima Y, Saito T, Akiba D, Kitagawa T, Ueta K, Miyaoka R, Nishizawa S: A pitfall of fluorescence-guided surgery with 5 -aminolevlunic acid for the treatment of malignant brain tumor -case report. ALAPorphyrin Sci 2:61-66, 2012

17. Yamamoto J, Yamamoto S, Hirano T, Li S, Koide M, Kohno E, et al: Monitoring of singlet oxygen is useful for predicting the photodynamic effects in the treatment for experimental glioma. Clin Cancer Res 12:7132-7139, 2006 